\title{
PENGARUH PARTISIPASI MASYARAKAT DAN TRANSPARANSI KEBIJAKAN TERHADAP PENGAWASAN ANGGARAN DANA DESA DI KECAMATAN DELIMA KABUPATEN PIDIE
}

\author{
Maisur $^{1}$, Ramzijah $^{2}$ \\ ${ }^{1,2}$ Fakultas Ekonomi Universitas Jabal Ghafur Sigli \\ 1'maisurmy@gmail.com, 2ramzijah@unigha.ac.id
}

\begin{abstract}
This research is aimed to test the effect of the society participation and policy transparency of monitoring of the village fund budget. The variable used in this thudy is the application of accounting information systems. samples in this study with total of 100 . Technique of sampling is applied with random sampling. The analysis method use multiple linear regression. The results of research show that the society participation and policy transparency have significant effect on monitoring of the village fund budget.
\end{abstract}

Keywords : society participation,policy transparency, monitoring of the village fund budget.

\begin{abstract}
ABSTRAK
Penelitian ini bertujuan untuk menguji pengaruh partisipasi masyarakat dan transparansi kebijakan terhadap pengawasan anggaran dana desa. Variabel yang digunakan pada penelitian ini adalah partisipasi masyarakat dan transparansi kebijakan. Sampel yang digunakan dalam penelitian ini sebanyak 100 orang. Pemilihan sampel dilakukan dengan mengunakan metode random sampling.Metode analisis yang digunakan adalah regresi linier berganda. Hasil penelitian menunjukkan bahwa Partisipasi masyarakat dan transparansi kebijakan berpengaruh terhadap pengawasan anggaran dana desa.
\end{abstract}

Kata kunci : Partisipasi masyarakat, transparansi anggaran, pengawasan anggaran dana desa.

\section{Pendahuluan}

Dengan pengelolaan dana sendiri, desa telah ditempatkan sebagai subjek sesungguhnya dari pembangunan karena mendorong perangkat desa dan masyarakat aktif memegang peranan pembangunan karena merekalah yang memahami secara utuh persoalan dan kebutuhan desa. Namun dalam kenyataannya bahwa Pengelolaan dana gampong pada tingkat desa di Aceh saat ini masih cenderung tertutup. Kondisi itu dapat menimbulkan potensi korupsi yang besar, karena masyarakat desa susah mengakses dana tersebut (Firdaus,2018). Hal ini terbukti banyak masyarakat yang melaporkan tertutupnya pengelolaan dana desa kepada pihak inspektorat kabupaten/kota, dan ini juga terjadi di kabupaten Pidie dimana laporan masyarakat dari tahun 2016 sebanyak 20 kasus pengaduan masyarakat meningkat drastis pada tahun 2017 yaitu 105 kasus pengaduan masyarakat (Inspektorat Kabupaten Pidie, 2017) Oleh karena itu diperlukan peran masyarakat dalam melakukan pengawasan pelaksanaan anggaran dana desa untuk mencegah terjadinya penyelewengan. Untuk itu masyarakat harus berpartisipasi secara aktif dalam musyawarah desa. Setiap masyarakat mempunyai hak untuk ikut serta dalam menentukan alokasi penggunaan dana desa. Partisipasi masyarakat dalam penggangaran harus dilakukan pada setiap tahapan dalam siklus anggaran mulai dari penyusunan, pelaksanaan, sampai dengan pertanggungjawaban (Syamsi, 2014). Selain 
dari partisipasi masyarakat juga diperlukan transparansi kebijakan yaitu prinsip yang menjamin kebebasan bagi setiap orang untuk meperoleh informasi tentang penyelenggaraan pemerintahan atau ketererbukaan dalam membuat kebijakan keuangan desa sehingga dapat diketahui dan diawasi oleh masyarakat. Birokrasi yang menjalankan kebijakan publik secara transparan serta memberikan layanan informasi dengan baik, jelas akan mendapatkan kepercayaan yang besar dari warga masyatakat. Makin menguatnya kepercayaan masyarakat pada penyelenggaraan pemerintah, disanalah sesunguhnya menjadi ukuran legitimasi yang bisa terbangun secara kokoh. Berdasarkan permasalahan diatas maka peneliti perlu mengkaji lebih mendalam mengenai pengaruh partisipasi masyarakat dan transparansi kebijakan terhadap pengawasan anggaran desa di Kecamatan Delima

\section{Kajian Pustaka}

\section{Pengertian Partisipasi Masyarakat Dan Transparansi Kebijakan}

Salah satu partisipasi masyarakat dengan melakukan pencarian ide dan saransaran dari pada komponen masyarakat untuk menjadikan sebagai tolak ukur dari proses pembangunan. Menurut Domae dan Tjajanulin (2011) partisipasi mayarakat adalah dimana masyarakat dapat mengambil peran baik dalam proses perencanaan, pelaksanaan dan memantau kebijakankebijakan yang lansung mempengaruhi kehidupan mereka. Inilah peran masyarakat yang memiliki hak penuh, dimana masyarakat memiliki kuasa dan mempunyai sumberdaya.

Oleh karena itu, pemerintahan desa harus membuat dokumen dalam proses perencanaan pembanguna dalam bentuk rencana kerja pemerintah (RKP). Menurut Utami dan Sofyan (2013) bahwa proses penyusunan RKP desa dapat dibagi menjadi tiga tahap yaitu :

1. Tahap persiapan musrenbang desa, yaitu untuk mengkaji ulang RPJM (Rencana Pembangunan Jangka Menengah), mengkaji ulang dokumen RKP desa tahun sebelumnya dan melakukan analisis data.

2. Tahap pelaksanaan musrenbang desa, ini merupakan forum pertemuan warga dan berbagai kepentingan untuk memaparkan hasil analisis.

3. Tahap sosialisasi, yaitu melakukan sosialisasi dokumen RKP desa kepada masyarakat dan seluruh pemangku kepentingan.

\section{Faktor-Faktor Yang Mempengaruhi Partisipasi Masyarakat}

Menurut Hasan (2014) bahwa faktorfaktor partisipasi masyarakat dipengaruhi oleh faktor internal dan faktor eksternal:

1. Faktor internal, untuk berpartisipasi dalam suatua kegiatan dipengaruhi oleh karakteristik individu. Karakteristik individu mencakup, tingkat pendidikan, umur, etnis, pekerjaan, bahasa, jumlah pendapatan, jumlah beban keluarga, pengalaman kelompok.

2. Faktor eksternal, pihak pengelola proyek harus menjalin hubungan dengan sasaran yang dapat mempengaruhi partisipasi karena sasaran akan dengan sukarela terlibat dalam suatu proyek, jika pihak pengelola positif dan menguntungkan mereka. selain dari pada itu.

Namun dalam penelitian yang dilakukan oleh Kusuma (2012) bahwa dari empat karakteristik masyarakat yang diteliti hanya variabel usia dan tingkat pendidikan yang memberikan pengaruh signifikan terhadap tingkat partisipasi. Sedangkan 
tingkat pendapatan dan jumlah beban keluarga tidak berpengaruh secara signifikan.

\section{Transparansi Kebijakan}

Transparansi kebijakan adalah penjabaran dari pelaksanaan aktivitas dan tugas yang bersifat terbuka bagi masyarakat dari proses kebijakan, perencanaan pelaksanaan, pengontrolan/pengendalian, serta mudah diakses oleh semua pihak yang membutuhkan informasi. Sedangkan menurut Utami dan Sofyan (2013) transparansi kebijakan merupakan pelaksanaan kegiatan dan tugas serta menjamin kebebasan bagi setiap orang untuk mengakses informasi tentang penyelenggaraan pemerintah baik tentang kebijakan, proses pembuatan dan pelaksanaannya serta hasil yang telah dicapai.Namun dalam pengukuran transparansi bisa dilakukan dengan arus informasi yang bersumber dari pemerintah tersebut. Keterbukaan informasi diharapkan akan menghasilkan kebijakan yang dibuat berdasarkan pada preferensi masyarakat.

Namun dalam penelitian oleh Anggraini (2013) transparansi kebijakan berupa keterbukaan informasi, namun informasi bisa saja dari laporan keuagan yang terbuka dan jujur pada stekholder yang memiliki kepentingan dan berdasarkan pertimbangan bahwa masyarakat berhak mengetahui secara terbuka dan menyeluruh terhadap pelaksanaan kegiatan dan pertanggungjawaban terhadap laporan keuangan.

\section{Prinsip Transparansi Kebijakan}

Menurut Khairuddin dan Erlanda (2016) bahwa prinsip transparansi terdiri dari dua aspek yaitu:
1. Aspek komunikasi publik oleh pemerintah

2. Hak masyarakat terhadap akses informasi
Namun dalam menerapkan dua aspek tersebut apabila pemerintah bersedia untuk terus memperbaiki kinerja menuju pemerintahan dan tata kelola yang lebih baik. Sedangkan menurut Utami dan Sofyan (2013) ada 6 prinsip untuk membuat transparansi kebijakan yang efektif yaitu :

1. Memberikan informasi yang mudah bagi masyarakat untuk digunakan.

2. Adanya publikasi dan media mengenai proses kegiatan dan detail keuangan.

3. Adanya laporan berkala mengenai pendayagunaan sumber daya dalam perkembangan proyek yang dapat diakses oleh umum.

4. Laporan tahunan

5. Website atau media publikasi organisasi.

6. Pedoman dalam penyebaran informasi Namun dalam peraturan pemerintah (PP) nomor 58 menjelaskan bahwa pengelolaan keuangan pemerintah harus berlandaskan ekonomis, efektif, transparan, dan bertanggung jawab dengan mengedepankan azas keadilan, kepatuhan, dan manfaat untuk masyarakat.

\section{Indikator Transparansi Kebijakan}

Adapun indikator-indikator transparansi kebijakan menurut Anggraini (2013) adalah sebagai berikut:

a. Penyediaan dan akses informasi yang jelas tentang perencanaan, prosedur pelaksanaan dan pertanggung jawaban.

b. Adanya musyawarah yangmelibatkan masyarakat.

c. Keterbukan proses pengelolaan

d. Keterbukaan informasi tentang dokumen pengelolaan anggaran dana desa.

\section{Pengawasan Anggaran}

Perlunya pengawasan anggaran bertujuan untuk dapat meminimalisir penggunaan anggaran yang tidak sesuai dengan perencanaan, tidak efektif dan efesien.Menurut Firdaus (2018) bahwa pengawasan dapat menciptakan good 
governance dalam menyelenggaran pemerintah sehingga terhindar dari praktekpraktek penyelewengan. Sebenarnya pengawasan tidak hanya tanggungjawab dari istitusi pengawasan, namun juga oleh masyarakat. Menurut Coryanata (2013) pengawasan adalah proses pemeriksaan terhadap semua kegiatan dilakukan secara menyeluruh dengan tujuan agar kegiatan tersebut berjalan sesuai dengan peraturan yang berlaku.

\section{Indikator Pengawasan Anggaran}

Adapun indikator pengawasan anggaran menurut Utami dan Syofyan (2013) adalah sebagai berikut:

1. Akurat (Accurate), informasi atas kinerja atas anggaran harus akurat.

2. Evaluasi kegiatan.

3. Tepat waktu (Timely) pencatatan transaksi harus tepat waktu.

4. Pencatatan transaksi berdasarkan bukti.

5. Dokumentasi bukti transaksi

6. Sistem pengawasan pelaksanaan tugas

7. Laporang keuangan sesuai standar akuntansi.

\section{Metode Penelitian}

\section{Lokasi Penelitian}

Penelitian ini dilaksanakan di Kecamatan Delima Kabupaten Pidie, hal ini dikarenakan banyaknya desa di kecamatan Delima yang bermasalah baik dalam pelaksanaan kegiatan maupun dalam pertanggungjawaban.

\section{Populasi dan Sampel}

Populasi dalam penelitian ini adalah seluruh masyarakat yang berjumlah 20,326 responden. Mengingat banyak dan luasnya sebaran populasi, maka akan ditempuh cara pengambilan sampel kebijakan ini secara metodologi dibenarkan sepanjang sampel mampu mempresentasikan populasi (sugiyono, 2007:74).

Teknik penentuan besaran sampel pada penelitian ini menggunakan rumus Slovin. Rumus Slovin diterapkan untuk jumlah populasi yang telah diketahui (Slovin dalam Kriyantono, 2007:35). Formula tersebut adalah sebagai berikut:

$$
\mathrm{n}=\frac{\mathrm{N}}{1+\mathrm{Ne}^{2}}
$$

keterangan : $\mathrm{n}=\mathrm{Jumlah}$ Sampel $\mathrm{N}=$ Jumlah Populasi

$\mathrm{e}=$ Tingkat Kesalahan Sebesar 0,1

besarnya populasi diketahui sebesar 20,326 (BPS, 2018). Jadi besarnya sempel yang digunakan adalah :

$$
n=\frac{20,326}{1+20,326 \times 0,1^{2}} \text { atau } \frac{20,326}{1+20,326(0,01)}
$$$$
\frac{20,326}{204,26}=99,6
$$

Berdasarkan perhitungan diatas, maka sampel yang diambil dalam penelitian adalah 100 responden.

\section{Teknik Pengumpulan Data}

Teknik pengumpulan data dilakukan dengan cara :

1. Wawancara (interview) langsung dengan pihak-pihak yang berkompetisi untuk memperoleh data penelitian seperti tokoh masyarakat dan perangkat desa.

2. Kusioner adalah suatu cara pengumpulan data dengan memberikan dan menyebarkan daftar pertanyaan kepada responden yaitu masyarakat dan perangkat desa.

3. Dokumentasi adalah pengumpulan data berupa buku-buku yang memuat datadata tentang kebijakan desa, peraturan desa, RAPBG dan laporan pertatanggung jawaban.

\section{Analisa Data}

Analisis data dengan mengunakan metode regresi linier berganda bertujuan untuk untuk menguji dan menganalisis pengaruh variabel partisipasi masyarakat dan transparansi kebijakan terhadap pengawasan anggaran desa. Data diolah dengan menggunakan program Statistik Package For social Science (SPSS). Adapun bentuk matematisnya regresi linier berganda sebagai berikut: 
$\mathrm{Y}=\alpha+\beta_{1} \mathrm{X}_{1}+\beta_{2} \mathrm{X}_{2}+\varepsilon$

Keterangan:

$$
\begin{aligned}
\mathrm{Y} & =\text { Pengawasan Anggaran Desa } \\
\alpha & =\text { Konstanta } \\
\beta & =\text { Koefisien Regresi } \\
\mathrm{X}_{1} & =\text { Partisipasi Masyarakat } \\
\mathrm{X}_{2} & =\text { Trasparansi Kebijakan } \\
\varepsilon & =\text { Error term }
\end{aligned}
$$

\section{Rancangan Pengujian Hipotesis}

Setelah dilakukan pengukuran variabel dalam penelitian ini, maka dilakukan pengujian hipotesis. Untuk menentukan menerima atau menolak hipotesis yang diajukan. Karena penelitian ini menggunakan metode populasi, maka dilakukan uji signifikansi baik t-test untuk pengaruh secara parsial maupun $F$-test untuk pengaruh secara bersama-sama. Kesimpulan penelitian diambil langsung dari nilai koefesien regresi masing-masing variabel independen.

Untuk menguji pengaruh partisispasi masyarakat dan transparansi kebijakan terhadap pengawasan anggaran dana desadapat dilakukan dengan langkahlangkah sebagai berikut:

- Menentukan hipotesis nol (H0) dan Hipotesis alternatif (Ha)

- H0 : $\beta,=$ Partisipasi Masyarakat dan transparansi kebijakan tidak berpengaruhterhadap pengawasan anggaran dana desa.

- Ha : paling sedikit ada satu $\beta i(i=1,2) \neq 0$; partisipasi masyarakat dan transparansi kebijakan berpengaruh terhadap pengawasan anggaran dana desa.

- Jika $\beta=0$; H0 diterima

- Ha : paling sedikit ada satu $\beta \mathrm{i}(\mathrm{i}=1,2,3) \neq$ 0 ; H0 ditolak

\section{Hasil Penelitian dan Pembahasan Pengujian Validasi dan Reliabilitas}

Hasil uji validitas menunjukkan

\begin{tabular}{|c|c|c|c|c|}
\hline \multicolumn{5}{|c|}{ Hasil Uji Validitas } \\
\hline Variabel & Item & $\begin{array}{c}\text { Koefisien } \\
\text { korelasi }\end{array}$ & $\begin{array}{c}\text { Nilai } \\
\text { kritis } \\
(\mathrm{N}=100)\end{array}$ & Keterangan \\
\hline $\begin{array}{l}\text { Partisipasi } \\
\text { Masyarakat } \\
\left(\mathrm{X}_{1}\right)\end{array}$ & $\begin{array}{l}X_{1.1} \\
X_{1.2} \\
X_{1.3} \\
X_{1.4} \\
X_{1.5} \\
X_{1.6} \\
X_{1.7} \\
X_{1.8} \\
X_{1.9} \\
X_{1.10}\end{array}$ & $\begin{array}{l}0,355 \\
0,607 \\
0,736 \\
0,440 \\
0,818 \\
0,770 \\
0,868 \\
0,690 \\
0,558 \\
0,612\end{array}$ & 0,194 & $\begin{array}{l}\text { Valid } \\
\text { Valid } \\
\text { Valid } \\
\text { Valid } \\
\text { Valid } \\
\text { Valid } \\
\text { Valid } \\
\text { Valid } \\
\text { Valid } \\
\text { Valid }\end{array}$ \\
\hline $\begin{array}{c}\text { Transparans } \\
\text { i Kebijakan } \\
\qquad\left(\mathrm{X}_{1)}\right.\end{array}$ & $\begin{array}{l}X_{1.1} \\
X_{1.2} \\
X_{1.3} \\
X_{1.4} \\
X_{1.5} \\
X_{1.6} \\
X_{1.7} \\
X_{1.8} \\
X_{1.9} \\
X_{1.10}\end{array}$ & $\begin{array}{l}0,244 \\
0,457 \\
0,687 \\
0,457 \\
0,759 \\
0,684 \\
0,795 \\
0,665 \\
0,480 \\
0,631\end{array}$ & 0,194 & $\begin{array}{l}\text { Valid } \\
\text { Valid } \\
\text { Valid } \\
\text { Valid } \\
\text { Valid } \\
\text { Valid } \\
\text { Valid } \\
\text { Valid } \\
\text { Valid } \\
\text { Valid }\end{array}$ \\
\hline $\begin{array}{c}\text { Pengawasan } \\
\text { Anggaran } \\
\text { (Y) }\end{array}$ & $\begin{array}{l}Y_{1.1} \\
Y_{1.2} \\
Y_{1.3} \\
Y_{1.4} \\
Y_{1.5} \\
Y_{1.6} \\
Y_{1.7} \\
Y_{1.8} \\
Y_{1.9} \\
Y_{1.10}\end{array}$ & $\begin{array}{l}0,420 \\
0,319 \\
0,396 \\
0,430 \\
0,328 \\
0,577 \\
0,464 \\
0,682 \\
0,557 \\
0,309\end{array}$ & 0,194 & $\begin{array}{c}\text { Valid } \\
\text { Valid } \\
\text { Valid } \\
\text { Valid } \\
\text { Valid } \\
\text { Valid } \\
\text { Valid } \\
\text { Valid } \\
\text { Valid } \\
\text { Valid }\end{array}$ \\
\hline
\end{tabular}
rhitung sama dengan atau lebih besar dari r- kritis, maka dikatakan valid dan dapat digunakan untuk analisis selanjutnya.Hasil keseluruhan dari pengujian validitas data dapat dilihat Pada Tabel di bawah ini:

Sumber Data diolah, 2019

Hasil dari pengujian reliabilitas menunjukkan bahwa semua indikator yang mengukur masing-masing variabelnya telah sesuai.

\begin{tabular}{|c|l|c|c|c|}
\hline No & \multicolumn{1}{|c|}{ Variabel } & $\begin{array}{c}\text { Pertany } \\
\text { aan }\end{array}$ & $\begin{array}{c}\text { Cronbach } \\
\text { Alpha }\end{array}$ & Hasil \\
\hline 1 & Partisipasi Masyarakat & 10 & 0,854 & Reliabel \\
\hline 2 & Kinerja Manajerial & 10 & 0,887 & Reliabel \\
\hline 3 & Pengawasan Anggaran & 10 & 0,611 & Reliabel \\
\hline
\end{tabular}

Sumber data diolah, 2019

\section{Hasil Analisis Regresi Linier Berganda}

Interpretasi dari persamaan regresidigunakan untuk menetukan persamaan dalam penelitian yang dilakukan, yang dapat digunakan untuk menentukan model penelitian dan menjelaskan pengaruh masing-masing variabel terikat. Berdasarkan Tabel dibawah maka persamaan regresi 
dengan yang dapat dibentuk adalah sebagai berikut:

\begin{tabular}{|c|c|c|c|c|c|}
\hline \multicolumn{6}{|c|}{ Regresi Linier Berganda } \\
\hline \multirow[t]{2}{*}{ Model } & \multicolumn{2}{|c|}{$\begin{array}{l}\text { Unstandardized } \\
\text { Coefficients }\end{array}$} & \multirow{2}{*}{\begin{tabular}{|c|}
$\begin{array}{l}\text { Standardize } \\
\text { d } \\
\text { Coefficient }\end{array}$ \\
Beta
\end{tabular}} & \multirow[t]{2}{*}{$\mathrm{T}$} & \multirow[t]{2}{*}{ Sig. } \\
\hline & B & $\begin{array}{c}\text { Std. } \\
\text { Error }\end{array}$ & & & \\
\hline (Constant) & 1.091 & .093 & & 11.766 & .000 \\
\hline PM & .230 & .090 & .374 & 2.558 & .012 \\
\hline TK & .525 & .099 & .778 & 5.325 & .000 \\
\hline
\end{tabular}

Data diolah, 2019

\section{Pembahasan}

\section{Partisipasi Masyarakat Berpengaruh Positif Terhadap Pengawasan Anggaran Dana Desa}

Hipotesis yang pertama yang di ajukan didukung oleh data, dari hasil analisis didapatkan thitung $=2.258>$ ttabel $=1.660$ dan signifikan $=0,012<\alpha=0,05$. Dengan demikian H1 diterima dan Ho ditolak, artinya dapat berpengaruh yang signifikan antara partisipasi masyarakat terhadap pengawasan anggaran dana desa pada tingkat signifikansi $\alpha=0.05$. hal ini disebakan bahwa partisipasi masyarakat dalam pengawasan anggaran dana desa merupakan bentuk cara dalam bagian untuk menjadikan subjek atau pelaku dalam pembagunan desa. Oleh karena itu dengan adanya keterlibatan masyarakat dalam memberikan pandangan dan arahan sehingga penggunaan dana desa tepat pada sasaran dan sesuai dengan perencanaan. Namun disisi lain dengan adanya partisispasi masyarakat dapat meminimalisir akan terjadinya tindak pidana korupsi. Penelitian ini sesuai dengan penelitian yang dilakukan oleh Syamsi (2014) bahwa partisipasi masyarakat berpengaruh positif terhadap pengelolaan dana desa, dengan keterlibatan masyarakat sehingga dapat mengontrol penggunaan dana desa. Penelitian yang sama dilakukan olehIndriani et al(2019) bahwa partisipasi masyarakat berpengaruh positif dan signifikan, dalam penelitiannya menunjukkan bahwa dengan adanya partisipasi masyarakat sehingga penggunaan anggaran dapat dilakukan secara bijaksana dan efektif beserta efisien.

\section{Transparansi}

Kebijakan

\section{Berpengaruh Terhadap Pengawasan} Anggaran Dana Desa

Hipotesis yang pertama yang di ajukan didukung oleh data, dari hasil analisis didapatkan thitung $=5.328>$ ttabel $=1.660$ dan signifikan $=0,000<\alpha=0,05$. Dengan demikian $\mathrm{H}_{1}$ diterima dan Ho ditolak, artinya dapat berpengaruh yang signifikan antara transparansi kebijakan terhadap pengawasan anggaran dana desa pada tingkat signifikansi $\quad \alpha=0.05 . h a l \quad$ ini disebabkan bahwa transparansi merupakan prisip keterbukaan yang memungkinkan masyarakat untuk mengetahui dan mendapatkan akses informasi seluas-luasnya tentang keuangan desa dan bentuk pengelolaan dana desa. Oleh karena itu, transparansi merupakan salah satu bentuk untuk meningkatkan akuntabilitas dalam pengelolaan keuangan desa. Dimana dalam penelitian yang dilakukan oleh Coryanata (2012) bahwa transparansi kebijakan adalah modal utama dalam mengedapankan akuntabilitas pengelolaan keuangan, sehingga menjadikan bahwa prinsip transparansi akan menjadikan tingkat kecurangan dalam pelaksanaan dan pengelolaan dapat di minimalisir. Menurut Amelia et.al(2018) bahwa transparansi kebijakan berpengaruh positif terhadap pengawasan anggaran, karena dengan adanya keterbukaan informasi akan dapat meningkatkan kepercayaan masyarakat terhadap pengelolaannya. Namun berbeda dengan penelitian yang dilakukan oleh Siswanto, Hafizrianda dan Antoh (2017) bahwa dalam penelitiannya mengatakan transparansi anggaran berpengaruh negatif. Hal ini disebabkan bahwa transparansi kebijakan masih sebagai wacana, namun dalam implementasi dalam tahap formalitas. 


\section{Kesimpulan dan Saran \\ Kesimpulan}

Kesimpulan Berdasarkan hasil pengujian hipotesis dapat disimpulkan bahwa:

1. Partisipasi masyarakat berpengaruh positif dan signifikan terhadap pengawasan anggaran dana desa. hal ini disebakan bahwa dengan adanya partisipasi masyarakat dapat menjamin terlaksananya pengelolaan anggaran dana desa sesuai dengan perencanaan dan dapat meminimalisir tindak pidana penyimpangan anggaran .

2. Transparansi kebijakan berpengaruh positif dan signifikan terhadap pengawasan anggaran dana desa. Dengan keterbukaan informasi baik itu anggaran maupun kebijakan kepada publik, sehingga dengan mudahnya masyarakat bisa mengawasi pelaksanaan terhadap kegiatan tersebut.

\section{Saran}

1. Diharapkan kepada pemerintahan desa untuk melibatkan masyarakat dalam berbagai kegiatan terutama dalam pembahasan anggaran dana desa. Hal untuk meminimalisir tingkat kecurigaan masyarkat terhadap pemerintah desa.

2. pemerintahan desa harus membuka informasi kepada masyarakat seluasluasnya. Hal ini untuk menjamin tidak terjadinya penyalahgunaan wewenang jabatan.

3. Diharapkan pemerintah kecamatan harus mengontol terhadap pemerintahan desa supaya tidak terjadinya tindakan otoriter di tengah masyarakat yang dilakukan oleh aparatur desa

\section{Daftar Pustaka}

Firdaus, Andi (2018) Pola Korupsi dan Pengawasan Dana Desa. Artikel. http://aceh.tribunnews.com/2018/07/ 19/pola-korupsi-dan-pengawasandana-desa.
Ispektorat Kabupaten Pidie (2018) buku panduan pelaksanaan pengawasan dana desa. Adani. Sigli.

Syamsi, Syahrul (2014) Partisipasi Masyarakat Dalam Mengontrol Penggunaan Anggaran Dana Desa. Jurnal Ilmu Sosial dan Politik. Vol. 3, No. 1. ISSN 2442-6962.

Maria Rios dan Bastida,Francisco (2014) Budget Transparency and Legislative Budgetary Oversight: An International Approach. American Review of Public Administration. /journalsPermissions.nav DOI: 10.1177/0275074014565020. 1-23.

Domae, Tjajanulin (2011). Sound Governence, Meningkatkan Kapasitas Kelompok Miskin dan Mengadpokasi Pemerintah Desa, Universitas Berawijaya, Press (UB Preess).

Paavola, M. (2012). The Impact Of Village Development Funds On Community Welfare InThe Lao People's Democratic Republic. ISSN. 07868170.

Hasan, Thoha (2014) Pengaruh Partisipasi Masyarakat, Pendanaan Dan Kualitas Aparatur Terhadap Keberhasilan Pelayanan Pendidikan Di Kabupaten Karawang. Jurnal Unsika. ISSN. 1412-86676. Vol. 10 No.22.

Utami, Kurnia dan Efrizal Syofyan (2013) Pengaruh Pengetahuan Dewan Tentang AnggaranTerhadap Pengawasan Keuangan Daerah Dengan Variabel Pemoderasi Partisipasi Masyarakat Dan Transparansi Kebijakan Publik. Jurnal WRA. Vol.1, No.1.

Kusuma, Marhendra. (2012) pengaruh akuntabilitas terhadap transparansi penyusunan laporan keuangan 
pemerintah daerah cahaya aktiva". Vol.02 no.02.

Anggraini (2013) Transparansi, Partisipasi, dan Akuntabilitas Pengelolaan Anggaran Dana BOS Dalam

4. dalanPibeghagaRikatindikSGIA Pacarkeling VIII Surabaya. Jurnal Kebijakan Publik. ISSN 2303 - 341X. vol. 1 No.2.
Khairuddin dan Erlanda, Rina (2016) Pengaruh Transparansi Dan Akuntabilitas Laporan Keuangan Pemerintah Daerah (LKPD) Terhadap Tingkat Korupsi Pemerintah Daerah. 